\title{
THE HEROIC UNDERTAKING? THE SEPARATE AND DISSENTING OPINIONS OF JUDGE WEERAMANTRY DURING HIS TIME ON THE BENCH OF THE INTERNATIONAL COURT OF JUSTICE
}

\author{
Duncan French*
}

\section{INTRODUCTION}

The purpose of this paper is to survey the work of Christopher Gregory Weeramantry while he was a judge at the International Court of Justice. The 1990s - the period during which Weeramantry served on the International Court - formed a significant decade for the judicial development of international law, and Judge Weeramantry was a notable member of the bench at this time. Rising to the position of Vice-President, Weeramantry made a significant mark on the jurisprudence of the International Court. While it is virtually impossible to ascertain his, as with any judge's, role in the deliberations of the wider Court, ${ }^{1}$ Weeramantry frequently exercised his right under the Court's statute ${ }^{2}$ and its rules ${ }^{3}$ to append separate (sometimes known as "individual") and dissenting opinions. Though maybe not as frequent in his opinions and declarations ${ }^{4}$ as some judges, ${ }^{5}$ Weeramantry nonetheless left

\footnotetext{
* PhD, Senior Lecturer in Law, University of Sheffield, United Kingdom: d.french@ sheffield.ac.uk. ${ }^{1}$ Article 21(1), Rules of Court: "The deliberations of the Court shall take place in private and remain secret'. See R. Higgins, "Reflections from the International Court" in M. Evans (ed.), International Law (Oxford: Oxford University Press, 2003) 3: "Only those present in the Deliberation Chamber can know what views were held, by whom, and on what grounds".

2 Article 57, Statute of the Court: "If the judgment does not represent in whole or in part the unanimous opinion of the judges, any judge shall be entitled to deliver a separate opinion".

3 Article 95(2), Rules of Court: "Any judge may, if he so desires, attach his individual opinion to the judgment, whether he dissents from the majority or not ... The same shall also apply to orders made by the Court". See also article 107(3) which provides, mutatis mutandis, for the attachment of individual opinions to an advisory opinion.

${ }^{4}$ Article 95(2), Rules of Court: "a judge who wishes to record his concurrence or dissent without stating his reasons may do so in the form of a declaration." See also article 107(3) which provides, mutatis mutandis, for the issuing of a declaration as regards an advisory opinion.
}

Asian Yearbook of International Law, Volume 11 (B.S. Chimni et al., eds.)

(C) 2006 Koninklijke Brill NV. Printed in The Netherlands, pp. 35-68. 
the International Court with a not insignificant list of separate and dissenting opinions. ${ }^{6}$

Although it is somewhat artificial to separate his understanding of international law whilst on the bench with his writings both before and $\operatorname{after}^{7}$ his judicial career, the opinions nevertheless stand on their own merit and are worthy of analysis in their own right. In particular, this paper will focus upon certain general themes that can be discerned from his opinions. Ranging from the importance of fairness in dispute settlement to the role of law in international affairs and his belief in the centrality of international adjudication in this endeavour, the paper will show how Weeramantry's understanding of international law directly affected his legal analysis. It will also introduce the patterns of reasoning and methodology often employed by Weeramantry in reaching conclusions on the legal issues that came before the Court.

In conclusion, it will be argued that despite such a legacy - or possibly, those more critical might wonder, because of it - there is a very real risk that Weeramantry's time at the International Court is in danger of being either seriously misinterpreted or ignored altogether; that while it stretches the truth beyond all reasonableness to say Weeramantry attempted, in his time on the bench, to transform the International Court's understanding of international law (the so-called "heroic undertaking" ${ }^{\prime 8}$ ), it would nevertheless be foolish to neglect the very rich - if inchoate - jurisprudence that he left behind.

\section{THE OPINIONS AND REASONING OF JUDGE WEERAMANTRY}

Weeramantry was elected to serve as a judge on the International Court as from 6th February 1991; following his failure to be re-elected in 1999, his term of office

\footnotetext{
5 One instantly recalls Shigeru Oda. As has been written, "[a]s a judge he is a study in independence. His resolution is legendary. At the ICJ, he has produced an unmatched number of dissents and separate opinions ... In none of them was he joined by another member of the Court." (M. Reisman, "Judge Shigeru Oda: A Tribute to an International Treasure", 16 Leiden Journal of International Law (2003) 61).

${ }^{6}$ See the attached annex for a list of Weeramantry's separate and dissenting opinions, as well as a separate list of his declarations.

${ }^{7}$ See, for instance, C. Weeramantry, The World Court, Its Conception, Constitution and Contribution (Sarvodaya, 2002) and Universalising International Law (Leiden/Boston: Martinus Nijhoff Publishers, 2004).

${ }^{8}$ A term devised from the following comment: "[T]hose with authority to interpret the law have an opportunity and responsibility to bring this utopic possibility a step closer to social and political reality ... an undertaking that Weeramantry has heroically sought to actualize in his career, and with particular intensity during his brief period as a judge on the International Court of Justice." (R. Falk, "The Coming Global Civilization: Neo-Liberal or Humanist?" in A. Anghie and G. Sturgess (eds.), Legal Visions of the 21st Century: Essays in Honour of Judge Christopher Weeramantry (The Hague/London/Boston: Kluwer Law International, 1998) 17. Emphasis added).
} 
as a permanent judge came to an end nine years after it had started. ${ }^{9}$ During that period, Weeramantry and his colleagues were faced with an increasing workload, covering a myriad of legal issues. These included (i) the exceptionally important if arguably somewhat abstract ${ }^{10}$ - question of the legality of nuclear weapons; (ii) seemingly unexceptional bilateral disputes; ${ }^{11}$ (iii) legal aspects arising from some of the most contentious political disputes of the period (the Lockerbie air crash, ${ }^{12}$ accusations of genocide during the bloody break-up of former Yugoslavia, ${ }^{13}$ and the NATO "humanitarian" intervention in Kosovo ${ }^{14}$ ), and (iv) those disputes that can only be described as legal "gems": $\operatorname{cases}^{15}$ that provided the Court with an unexpected opportunity for the judicial development of international law. ${ }^{16}$

In many - though by no means all of the - cases decided between 1991 and 2000, Weeramantry issued a separate or dissenting opinion; declarations were less frequent. However, there were a number of cases when Weeramantry did not depart individually from the collective opinion, ${ }^{17}$ and these included a number of the later cases where he was acting president ${ }^{18}$ to the Court. It would be purely speculative to consider

9 Of course, he may still be appointed as a judge ad hoc, as he was in Case concerning Sovereignty over Pulau Ligitan and Pulau Sipadan (Indonesia/Malaysia) (2002).

${ }^{10}$ Legality of the Use by a State of Nuclear Weapons in Armed Conflict, ICJ Rep.1996, at 162, dissenting opinion: "a distinction must be made between a question which is abstract in the sense of being unrelated to reality, and one which is abstract in the sense of being theoretical, though related to reality ... Few issues in the real world can be so live and cause such universal concern as the question whether or not the use of nuclear weapons is compatible with basic principles of State responsibility."

${ }^{11}$ For example, Case concerning the Arbitral Award of 31 July 1989 (Guinea-Bissau v. Senegal) (1991). Although the case may have appeared rather pedestrian in comparison with many of the other disputes Weeramantry had to consider, the arbitral process on which the dispute before the International Court was based was anything but unexceptional, and Weeramantry's dissenting opinion is also interesting, particularly for the emphasis he placed on the "object and purpose" of a text in trying to establish the appropriate interpretation.

12 Cases concerning Questions of Interpretation and Application of the 1971 Montreal Convention arising from the Aerial Incident at Lockerbie (Libyan Arab Jamahiriya v. United States of America) (Libyan Arab Jamahiriya v. United Kingdom) (1992 \& 1998).

${ }_{13}$ Case concerning Application of the Convention on the Prevention and Punishment of the Crime of Genocide (Bosnia and Herzegovina v. Yugoslavia (Serbia and Montenegro)) (1993, 1996 \& 1997).

${ }_{14}$ See the various Cases concerning Legality of Use of Force, Request for the Indication of Provisional Measures (1999).

15 See, for instance, Case concerning East Timor (Portugal v. Australia) (1995), and Case Concerning Gabèikovo-Nagymaros Project (Hungary/Slovakia) (1997)).

${ }^{16}$ Whether the Court always took full advantage of this opportunity is, however, another question.

17 Without its being a complete list, one might cite Maritime Delimitation and Territorial Questions between Qatar and Bahrain (Qatar v. Bahrain) Jurisdiction and Admissibility (1994 \& 1995), Case concerning Oil Platforms (Iran v. United States of America) Preliminary Objection (1996), Vienna Convention on Consular Relations (Paraguayv. United States of America) Request for the Indication of Provisional Measures (1998), and LaGrand (Germany v. United States of America) Request for the Indication of Provisional Measures (1999).

18 Article 32(1), Rules of Court: "If the President of the Court is a national of one of the parties in a case he shall not exercise the functions of the presidency in respect of that case." 
why Weeramantry did not issue separate or dissenting opinions in these cases. In particular, as regards those cases for which he was acting president, one might wonder whether Weeramantry either was more able to persuade his colleagues of the strength of his arguments when performing that function (there was thus no need for such opinions or declarations) or that he felt himself under more of an institutional restraint when acting in this capacity. ${ }^{19}$ Whatever the precise reasons for Weeramantry's choosing not to issue an opinion, including the possibility that he simply concurred with the reasoning of the majority in those cases, there is, nevertheless, more than enough cases from which to garner his opinions.

One should be aware, however, that there is an inherent danger in trying to identify certain general themes arising from the judicial writings of any judge. ${ }^{20}$ Crass oversimplification is at all costs to be avoided. However, Weeramantry - both as an academic and a judge - helps the critic in this regard as he often wore his individual views, to misuse a colloquialism, "on his sleeve". Four key themes can be discerned. First, Weeramantry was constantly seeking to operationalize notions of justice and fairness within his opinions, both as regards the substantive outcome of the case and procedurally within the Court. Achieving a fair and balanced result was an overriding concern for him throughout his opinions. Related to this was Weeramantry's rejection of any approach that was unduly formalistic and/or overly rigid in its application of the rules.

Second, Weeramantry resolutely sought to affirm the imperative of the rule of law in international affairs, both as a virtue in its own right and as a means of constraining the conduct particularly of those States considered most powerful and influential. Connected to this was his belief in the role of international adjudication - particularly the International Court - in upholding international law. Weeramantry had a special regard for the Court which, he recognized, possessed a unique responsibility to promote the law, both within the UN system and more generally as regards the international community. His refusal to bow to political interests was particularly apparent. It may also be noted that Weeramantry was deeply concerned with the workings of the Court; he raised, in numerous opinions, various aspects of the Court's jurisdiction and operation.

Third, there was a clear desire in many of the opinions to develop the law beyond its current confines and extent in light of what Weeramantry saw as certain deep-

${ }^{19} \mathrm{Cf}$. His dissent as regards the cases brought against Belgium, Canada, the Netherlands and Portugal by Yugoslavia in Case concerning Legality of Use of Force, Request for the Indication of Provisional Measures (1999). Note article 6(ii), 1976 Resolution Concerning the Internal Judicial Practice of the Court: "The President shall ex officio be a member of the drafting committee unless he does not share the majority opinion of the Court." This presumably includes the situation when the vicepresident is acting president.

${ }^{20} C f$. Reisman, n. 5, at 58: "Every decision maker leaves material that can be studied, but judges, particularly dissenting or concurring judges, leave a distinctive record, a written corpus in which the evidence of how he or she reacted to events and then rationalized and incorporated those reactions can be examined in terms of the forces that worked on and in their personalities. Studying material can help the student better explain how decisions are made, how law evolves and how and why the judge conceived of him- or herself and the judicial function. 
rooted values inherent within humanity: what Falk has referred to as the "embedded utopia". ${ }^{21}$ However, as a counter-point - yet, Weeramantry would undoubtedly argue, not in contradiction - to this, he often sought to affirm that he was deciding disputes on the basis of lex lata and not de lege ferenda. Whether, and how, this tension between seemingly divergent judicial functions was bridged by Weeramantry will also be touched upon.

The fourth theme arguably underpins the previous three. It is Weeramantry's approach to legal reasoning; it is characterized by a broadness in perspective and scope that is clearly distinctive from most, if not all, of his fellow judges. This approach had a number of different facets. It included a significant reliance on the object and purpose of a treaty in seeking its proper interpretation, ${ }^{22}$ it sought to utilize general principles from a range of domestic jurisdictions to help resolve legal issues, ${ }^{23}$ it often relied on hypothetical examples ${ }^{24}$ and reasoning by analogy, ${ }^{25}$ it was rich in cross-disciplinary, ${ }^{26}$ jurisprudential ${ }^{27}$ and literary ${ }^{28}$ material, and, arguably most idiosyncratic of all, was his use of "perspectives ... which international law has not yet tapped", ${ }^{29}$ including religious wisdom and the traditional practices of pre-Westphalian societies. It is on this last point that the final part of this paper will focus. Needless to say, Weeramantry roamed way beyond the Euro-centric standpoint for which international law and the Court as its representative has for so

21 Falk, n. 8, at 17.

22 See, for instance, Case concerning the Arbitral Award of 31 July 1989 (Guinea-Bissau v. Senegal), ICJ Rep. 1991, at 133: "Context and objects and purposes will tell us where in that vast spectrum our choice will fall."

23 See, for instance, Case concerning Sovereignty over Pulau Ligitan and Pulau Sipadan (Indonesia/Malaysia) Application by the Philippines for Permission to Intervene, ICJ Rep. 2001, at 634: "In the context of the paucity of international legal decisions ... [on intervention], any search for governing principles must draw heavily upon comparisons and contrasts with intervention principles in domestic legal systems."

24 See, for instance, Case concerning Kasikili/Sedudu Island (Botswana/Namibia), ICJ Rep. 1999, at 1184: "I have already advanced the illustration ... if it were expected in such hypothetical circumstances."

25 See, for instance, Case concerning Application of the Convention on the Prevention and Punishment of the Crime of Genocide (Bosnia and Herzegovina v. Yugoslavia) Counter-Claims, ICJ Rep. 1997, at 291: "Analogies in domestic jurisprudence are plentiful."

26 See, for instance, Case Concerning Gabèikovo-Nagymaros Project (Hungary/Slovakia), ICJ Rep. 1997, at 96-97: "[E]specially at the frontiers of the discipline of international law, it needs to be multi-disciplinary, drawing from other disciplines such as history, sociology, anthropology, and psychology such wisdom as may be relevant for its purpose".

27 See, for instance, Weeramantry's reliance in various opinions on the work of Rawls, Hart, Hohfeld, and Julius Stone.

${ }^{28}$ See, for instance, Legality of the Threat or Use of Nuclear Weapons, ICJ Rep. 1996, at 475: "H.G. Wells, in The World Set Free, visualized the creation of the bomb on the basis of information already known in 1913 resulting from the work of Einstein and others on the correlation of matter and energy."

${ }^{29}$ Case concerning Maritime Delimitation in the Area between Greenland and Jan Mayen (Denmark v. Norway), ICJ Rep. 1993, at 274. 
long been criticized. ${ }^{30}$ It is surely no surprise that Weeramantry named one of his first works subsequent to his career on the bench Universalising International Law; for this, one would suggest, is exactly what he sought to do as a judge.

A certain amount of academic comment has already been written on Weeramantry's contribution to international law, ranging from that which is little short of adulation, ${ }^{31}$ the balanced view, ${ }^{32}$ and the mildly sardonic ${ }^{33}$ right through to the more critical. ${ }^{34}$ While it may not always be possible to place oneself accurately on such a continuum, through an analysis of these four themes, it is hoped that a more rounded picture of Weeramantry's views may become clearer. Moreover, while it is very useful to be able to break up his opinions into these very rough categories, one must always remember that these are necessarily artificial divisions, particularly as Weeramantry's work, more so than that of many of his judicial contemporaries, is characterized by the existence of mutually supporting synergies between his interpretation of the substantive law and the reasoning by which he came to those conclusions.

However, before examining these themes in some detail, it may be worth pausing to consider what Weeramantry saw as his role as the individual judge, and what service he believed his separate and dissenting opinions could provide. Although these are clearly related to the judicial function of the Court as a whole, Weeramantry also recognized that the individual judge had a unique responsibility to speak his

${ }^{30}$ Case concerning Kasikili/Sedudu Island (Botswana/Namibia), ICJ Rep. 1999, at 1163: "We must not look for indicia of occupation in terms of settled housing or ordered agriculture, burial sites, or schools, for the very nature of this terrain prevented settled habitation in the manner known to Western jurisprudence and tradition."

31 R. Clark, "Review of C. Weeramantry, 'Universalising International Law", 99 AJIL (2005), at 298: "As a judge on the ICJ, he was known for his separate and dissenting opinions, which were guaranteed to be scholarly and probing, informed by a cross-cultural understanding, and infused with a spirit of respect and decency."

32 See Falk, both his comment, at n. 8 and further in the same paper: "[t]o this extent, I differ from Judge Weeramantry in his heroic and invaluable efforts to rely on international law to challenge some of the most dangerous and objectionable features of the existing world order." (at 32).

33 A. Boyle, "The Gabèikovo-Nagymaros Case: New Law in Old Bottles", 8 Yearbook of International Environmental Law (1997), at 14: "Judge Weeramantry's expansive and eloquent use of general principles of law will doubtless add to his reputation for creative and original perspectives on the legal process."

34 See generally, V. Lowe, "Sustainable Development and Unsustainable Arguments" in A. Boyle and D. Freestone (eds.), International Law and Sustainable Development: Past Achievements and Future Challenges (Oxford: Oxford University Press, 1999) who argues against Weeramantry's interpretation of sustainable development as a rule of customary international law. Lowe goes on to argue, however, that sustainable development possesses an "interstitial normativity" which he suggests "[i]f I read Judge Weeramantry's Opinion correctly, this (or something close to it) is the kind of normativity that he asserts is now possessed by sustainable development." (at 31) (cf. D. French, International Law and Policy of Sustainable Development (Manchester: Manchester University Press, 2005), at 71). 
mind. ${ }^{35}$ As he noted in Case concerning Legality of Use of Force (Yugoslavia $v$. Belgium) Request for the Indication of Provisional Measures (1999), "[t]his is thus a seminal moment in judicial history and I cannot permit it to pass without some suggestions which, though I am in a minority, may still, I hope, be of some utility." ${ }^{36}$ Of particular significance was his belief in the role of the individual opinion in elucidating legal ideas that went unaddressed or under-addressed in the principal judgment which, as he said, should be expressed, regardless of whether he was in the majority or the minority.

His often detailed discussion of such matters reflected his belief in the duality of the judicial function. ${ }^{37}$ Moreover, for Weeramantry, such individual analysis was as vital on procedural matters as it was in the development of the substantive law. As regards the latter, this can be most clearly seen in his separate opinion in Case concerning Maritime Delimitation in the Area between Greenland and Jan Mayen (Denmark v. Norway) (1993) where he noted that "[w]hile not intended to be a comprehensive exposition, it could also serve the limited purpose of drawing attention to aspects of [equity's] operation which, by remaining implicit, may remain unexplored ${ }^{38}$ Similar reasoning and wording are used to justify individual pronouncements on the Court's procedure; as he notes in Case concerning Sovereignty over Pulau Ligitan and Pulau Sipadan (Indonesia/Malaysia) Application by the Philippines for Permission to Intervene (2001), "I hope this separate opinion will be of some assistance in drawing attention to important aspects relating to intervention which will need further clarification in the procedural jurisprudence of the future" ${ }^{39}$ In both cases, a combination of his understanding of the judicial function, his particular stance on many legal issues of the day, a certain frustration - one might surmise with the collective drafting process, and a conviction in the usefulness of individual

35 See Legality of the Use by a State of Nuclear Weapons in Armed Conflict, ICJ Rep. 1996, at 170, dissenting opinion: "[a]n important feature of the tradition of judicial responsibility is that the judges 'will not hesitate to speak frankly and plainly on the great issues coming before them'." His steadfast refusal to accept the argument that the International Court should act timidly in the face of "the great issues" or deferentially in the face of entrenched political interests is arguably a constant feature of his opinions and, coincidentally, may - others would say, undoubtedly does - explain his failure to secure re-election for a second term of office.

36 ICJ Rep. 1999, at 184.

37 Case concerning East Timor (Portugal v. Australia), ICJ Rep. 1995, at 219: "The raison d'être of the Court's jurisdiction is adjudication and clarification of the law". See also his dissenting opinion in Request for an Examination of the Situation in Accordance with Paragraph 63 of the Court's Judgment of 20 December 1974 in the Nuclear Tests (New Zealand v. France) Case (1995), in which Weeramantry quoted with approval Gerald Fitzmaurice who had previously noted that "[i]nternational tribunals at any rate have usually regarded it as an important part of their function, not only to decide, but, in deciding, to expound generally the law having a bearing on the matters decided." (ICJ Rep. 1995, at 362 quoting G. Fitzmaurice, The Law and Procedure of the International Court of Justice (Vol. II) (Cambridge: Cambridge University Press, 1986), at 648).

38 ICJ Rep. 1993, at 278. Emphasis added.

39 ICJ Rep. 2001, at 651. 
viewpoints led, I think, Weeramantry to exercise his judicial right to issue an opinion as often as he did.

\subsection{Fairness and justice - the foundational goals?}

It is probably no surprise that Weeramantry was motivated by such ideals as fairness and justice and sought to promote them actively within his individual opinions. His previous academic work had more than highlighted his very real concern with upholding and infusing certain basic values within the rule of law. ${ }^{40}$ Earlier books included The Law in Crisis: Bridges of Understanding (1975); Equality and Freedom: Some Third World Perspectives (1976); Apartheid: The Closing Phase? (1980); The Slumbering Sentinels: Law and Human Rights in the Wake of Technology (1983); Law: The Threatened Peripheries (1984), and Nuclear Weapons and Scientific Responsibility (1987). Of particular note was Weeramantry's work as a member of the Commission of Inquiry on the Rehabilitation of Phosphate Lands in Nauru. In his subsequent book on the topic, his repudiation of the acquired rights doctrine (which, prima facie, supported the pre-existing extraction contracts so damaging to Nauru's natural resources) in favour of the interests of the people of Nauru was firmly based on his clear belief in the juridical notion of fairness. As he notes, "[t]o entrench such a contract - if indeed it was a contract - under the principle of acquired rights would amount to a perpetuation of the very element of unfairness which international law seeks to avoid." 41

This desire to achieve a fair and just result can be seen in almost all of his opinions; it was wide-ranging, applying not only to questions of the substantive law, but also in relation to the procedure of the International Court. As regards achieving fairness in the substantive law, this was as applicable to a "simple" bilateral dispute as it was to broader issues of global concern. In Case concerning the Arbitral Award of 31 July 1989 (Guinea-Bissau v. Senegal) (1991), in which the validity of a arbitral decision was under consideration, Weeramantry in his dissent noted that,

\footnotetext{
"In all these circumstances, one cannot conclude, unless compelled thereto by obligatory juristic principle, that an interpretation is legitimate which commits one party or the other to a situation so fraught with prejudice. Such a course neither offers a real solution to the solution before the Court nor ensures a fair determination for Guinea-Bissau of its exclusive economic zone and its fishery zone, which was among the principal purposes of the document under examination." 42
}

\footnotetext{
40 This is not to neglect Weeramantry's career as an advocate and then justice (1967-1972) of the Supreme Court of Sri Lanka, nor any of his other professional responsibilities over the years.

${ }^{41}$ C. Weeramantry, Nauru: Environmental Damage under International Trusteeship (Oxford: Oxford University Press, 1992), at 315. Emphasis added.

${ }^{42}$ ICJ Rep. 1991, at 172-173.
} 
This is an example par excellence of Weeramantry's approach. Firstly, it highlights the sheer artificiality of subdividing his opinions into separate themes; the quotation touches upon his mode of legal reasoning and his understanding of the judicial function, as well as - our current focus - his desire to achieve a fair and just outcome. Secondly, the reference to "unless compelled thereto by obligatory juristic principle" highlights recognition by Weeramantry that there may be positivist restraints upon his discretion to achieve "an interpretation [that] is legitimate". Thirdly, it shows us that fairness and justice were not, for him, merely abstract notions to be decided by a judiciary hermetically isolated from the "real world". The reference to "[s]uch a course neither offers a real solution ... nor ensures a fair determination" (sic) touches directly upon Weeramantry's view that the International Court should endeavour, whenever possible, to see as an integral whole the dispute before it, together with the practical consequences of its decisions. As he noted in his dissent in Legality of the Threat or Use of Nuclear Weapons (1996),

"By their very nature, problems in humanitarian law are not abstract, intellectual inquiries
which can be pursued in ivory-tower detachment from the sad realities which are their
stuff and substance. Not being mere exercises in logic and black-letter law, they cannot
be logically or intellectually disentangled from their terrible context. Distasteful though
it be to contemplate the brutalities surrounding these legal questions, the legal questions
can only be squarely addressed when those brutalities are brought into vivid focus."

Grounding a legal issue within its factual reality arguably serves three functions. Firstly, it re-connects law to community values and aspirations; for Weeramantry, law loses something very precious if it is divorced from the broader context from whence it came. Secondly, if law is ever to be an effective instrument of social control, it must be incisive in tackling the issues for which it was initially created. As he notes, to be "squarely addressed", the law can only truly be understood when the attendant "brutalities are brought into vivid focus". Thirdly, the authority and esteem of international law, and the Court which is its ultimate guardian, is significantly lowered if law is simply conceived as an exercise in "logic and black-letter law". This connexion between law and fact also raises difficult questions over the precise relationship between international adjudication and political power, on which Weeramantry has had much to say and on which, see below.

This concern for fairness is also present in his understanding of the mechanisms and purposes of international adjudication. It manifested itself most acutely in his opinions arising out of those aspects of the Cameroon $v$. Nigeria dispute in which Weeramantry was involved. Most significantly, Weeramantry dissented from the finding of jurisdiction in the Court's 1998 judgment on preliminary objections. Now, in the light of other opinions illuminating Weeramantry's rather expansive understanding of the jurisdiction of the Court, this seems rather out of line. ${ }^{44}$ However, for Weeramantry, although consensual jurisdiction, particularly under the optional clause,

43 ICJ Rep. 1996, at 444.

${ }^{44} \mathrm{See}$ below for a discussion on Weeramantry's approach to the role and jurisdiction of the Court. 
is to be supported and strengthened whenever possible, the facts of this case raised a wider issue of fairness. The issue was the lodging by one party of an "optional clause" declaration with the UN Secretary General under article 36(4) of the ICJ Statute, but the subsequent failure of the Secretary General to transmit this to the Court with a minimum of sufficient haste. The question was whether a case could be brought against another party by the declarant "irrespective of that other party's knowledge that such declaration has been lodged". ${ }^{45}$ The wording of article 36(4) certainly seems to require both the lodging and the communication of such a declaration. However, the view taken by the Court was that only the lodging of the declaration was required. As Weeramantry notes, "[i]t seems to me that such a proposition cannot be in conformity with either the express law or the essential philosophy governing the optional clause." 46

Leaving aside the "express law" ${ }^{47}$ the "essential philosophy" is of particular interest. As Weeramantry notes, to impose jurisdiction in such a case "is also in disharmony with the principles of equality, fairness good faith, and reciprocity." 48 Although Weeramantry was clearly minded as a judge to find jurisdiction whenever possible, the distinct unfairness in the current dispute and the consequent imbalance between the parties fell beyond that which could be accepted. Moreover, as with his dissent in Case concerning the Arbitral Award of 31 July 1989 (Guinea-Bissau $v$. Senegal) (1991), this reliance on fairness was not for abstract reasons of jurisprudence, but for very practically-orientated reasons. As Weeramantry notes, “[ $\mathrm{t}] \mathrm{he}$ vesting of jurisdiction in the Court is an important juristic act with major repercussions on State sovereignty ... This inequality can have practical repercussions."49 This pragmatic justice, while derived from a juridical ideal, was clearly grounded in the realities of the actual process of international adjudication.

Such a belief in fairness was also evident in two other opinions surrounding the dispute between Cameroon and Nigeria. In the previous Case concerning the Land and Maritime Boundary between Cameroon and Nigeria (Cameroon v. Nigeria) Request for the Indication of Provisional Measures (1996), Weeramantry joined with Judges Shi and Vereshchetin in a declaration explaining their reasons for voting against part of the dispositif. Their principal concern was that the provisional measures indicated "in effect leaves it to each Party to determine" where each of the respective armed forces of the two parties were positioned prior to a particular date. ${ }^{50}$ As the joint declaration continues, "[ $\mathrm{t}]$ he positions may well be contradictory, thus leaving

\footnotetext{
${ }^{45}$ Case concerning the Land and Maritime Boundary between Cameroon and Nigeria (Cameroon v. Nigeria) Preliminary Objections, ICJ Rep. 1998, at 362.

46 Idem.

47 ICJ Rep. 1998, at 376: "Other advantages of this view are that it would ... bring the operation of declarations under Article 36 within the express terms of the article which fashioned them."

48 ICJ Rep. 1998, at 362.

49 ICJ Rep. 1998, at 375. See also idem., at 376: "it would ... ensure fairness and reciprocity between the parties."

50 ICJ Rep. 1996, at 31.
} 
open the possibility of confusion upon the ground." ${ }^{, 51}$ Again, the concern is with being fair, in this case to both parties, in light of the factual difficulties raised by the Court's order. In addition, the declaration reflects a concern that the Court should avoid exacerbating with a vaguely-worded order an already precarious situation, but should rather be seeking to "dampen down" such conflicts.

Finally, Weeramantry was again in the minority in Request for Interpretation of the Judgment of 11 June 1998 in the Case concerning the Land and Maritime Boundary between Cameroon and Nigeria (Cameroon v. Nigeria) Preliminary Objections (Nigeria v. Cameroon) (1999). Weeramantry in his dissent disagreed with most of his colleagues and would have found the request for interpretation of the judgment - as permitted under article 60 of the Statute - admissible. Once again, one of the key reasons for Weeramantry's coming to this conclusion was his belief that the parties involved in a contentious dispute must be treated fairly. As he says, "[t]he clarification ... of the matter raised by Nigeria would also have achieved the great practical advantage of placing both Parties on clearer ground regarding the exact ambit of their future conduct of these proceedings." ${ }^{, 52}$

If the notion of fairness has been a governing theme in many of his individual opinions, one of the clearest manifestations of fairness, that of equity, has also received significant attention from Weeramantry. In his separate opinion in Case concerning Maritime Delimitation in the Area between Greenland and Jan Mayen (Denmark v. Norway) (1993), he conducted what he termed a "brief survey of a vast topic", namely, "the contribution of equity to an individual decision". ${ }^{53}$ In fact, this separate opinion was over sixty-five pages long, and structured into three substantial parts: the general equitable jurisdiction of the Court, particular invocations of equity in maritime delimitation, and what he refers to as "equity viewed in global terms". Despite clearly being not unrelated to the dispute before him, it reads as much as an academic piece as it does a judicial decision. Critically, it is an excellent discussion of equity in all its manifestations, ranging through the sources of equity, the various types of equity, and an interesting discussion concerning a priori and a posteriori employment of equity. In particular, the final part on the global nature of equity is a wonderful foretaste of both his later opinions on environmental jurisprudence and how Weeramantry can intertwine legal, jurisprudential, cultural, and religious sources to construct a singular argument. ${ }^{54}$ However, it is surely on the very edge of what a separate or dissenting opinion should be. Reminding oneself of Higgins' injunction that "judicial opinions should not be academic articles", 55 one cannot help but wonder whether Weeramantry has with this opinion crossed an unwritten rule.

\footnotetext{
${ }^{51}$ Idem.

52 ICJ Rep. 1999, at 42. Emphasis added.

53 ICJ Rep. 1993, at 278.

${ }^{54}$ ICJ Rep. 1993, at 278: "International law throughout its history has been richly interwoven with equitable strands of thought."

${ }^{55}$ Higgins, n. 1, at 4. One might also add that a characteristic of many of Weeramantry's opinions, in contrast to the opinions of many of his contemporaries, was a heavy reliance on footnotes, as often used in academic papers.
} 
Nevertheless, Weeramantry's focus on equity is a significant aspect of his understanding of fairness and justice as judicial tools. As he noted in the later case of Case concerning Kasikili/Sedudu Island (Botswana/Namibia) (1999), "this is a court not only of strict law, but of equity as well." ${ }^{, 56}$ An important aspect of this reliance on equity was a rejection of both formalism and an unduly rigid approach to legal rules. He noted in his dissent in Legality of the Threat or Use of Nuclear Weapons (1996) that "[i]f a glaring anomaly or absurdity becomes apparent and remains unquestioned, that discipline is in danger of being seen as floundering in the midst of its own technicalities." $" 57$

Although this rejection of formalism was most clearly related to his approach to legal reasoning (on which, see below), it was also relevant to his understanding of the role of the Court, especially in the pacific settlement of disputes involving international conflict. In a particularly contentious dispute brought by the remnant of Yugoslavia (Serbia and Montenegro) against those States of NATO involved in the humanitarian intervention in Kosovo and in which Yugoslavia sought provisional measures constraining further military intervention, Weeramantry made this very honest - some might say too honest - statement on his approach to the cases before the Court:

"It may be that for jurisdictional reasons the Court is totally unable to respond in the majority of the ten cases that have been brought before it. But in the cases where the Court can respond - be it in only one - I believe it should, because the issues involved are central to international order and the international rule of law, and when defined and applied by the Court will have their influence beyond the confines of the particular case." 58

Again, this quotation is an excellent example of numerous aspects of Weeramantry's approach. His belief in the imperative of the rule of law in international affairs and the Court's inherent right to promote international order will be considered later. However, what is also very striking about this statement is that although Weeramantry was prepared to accept - even if he did not agree entirely with - the Court's "jurisdictional reasons", he did not believe that this should necessarily hinder the Court, where it had the opportunity, "be it in only one [case]", to make its unique contribution to international peace. In particular, the clear policy element in the statement that a decision by the Court would have an "influence beyond the confines of the particular case" is in line with his rejection of a rather narrow jurisdictional remit for the Court. Returning to the first theme identified, fairness and justice were for Weeramantry overriding goals and, wherever possible, he felt that legal, operational, and jurisdictional restraints should be sufficiently malleable to accommodate and promote them.

\footnotetext{
56 ICJ Rep. 1999, at 1183.

57 ICJ Rep. 1996, at 485.

58 ICJ Rep. 1999, at 194.
} 


\subsection{International law and the International Court: bastions of legality?}

If fairness and justice were key values for Weeramantry, the international legal system and, more specifically, international adjudication were central to the way such values were to be secured within the international community. In particular, in many of his opinions, Weeramantry sought to emphasize the centrality of the rule of law in international relations and the role of the Court: to promote this. Moreover, he was also very well aware that, given the nature of the international law being as it was, ${ }^{59}$ the International Court was under an additional burden to reinforce the legality and integrity of the international system at every possible opportunity. This close connexion between international law and the International Court was clearly something that Weeramantry considered of utmost importance.

International law was worth defending, argued Weeramanty, because it was premised upon certain elementary values without which no society could live. These values were most vulnerable during times of conflict and stability. In Legality of the Threat or Use of Nuclear Weapons (1996), Weeramantry identified "[r]ationality, humanity and concern for the human future ... [as being] built into the structure of international law". ${ }^{60}$ In his later opinion in Case concerning Legality of Use of Force (Yugoslavia v. Belgium) Request for the Indication of Provisional Measures (1999), he was more specific in noting that "the peaceful resolution of disputes, the overarching authority of the United Nations Charter and the concept of the international rule of law" were the "fundamentals of the international legal order" ${ }^{61} \mathrm{He}$ went on to describe similar ideals as "the primordial principles underlying the Charter and the Statute", ${ }^{62}$ highlighting once again his deep regard for such notions. Although all members of the Court would undoubtedly be able to agree with such rhetoric, it was Weeramantry's detailed reliance on such principles and his use of them to inform his understanding of the legal points at issue that often separated him from his peers. ${ }^{63}$

Ensuring respect for such principles was especially critical when human life was at risk. His separate opinion in the 1996 judgment on the preliminary objections in Case concerning Application of the Convention on the Prevention and Punishment of the Crime of Genocide, in which he argued for the automatic succession of the Genocide Convention to successor States, was ultimately premised, for instance, on the argument that any other approach "would grievously tear the seamless fabric of international human rights protections, endanger peace, and lead the law astray from the Purposes and Principles of the United Nations." 64 There was often a strong sense

\footnotetext{
59 Case concerning the Arbitral Award of 31 July 1989 (Guinea-Bissau v. Senegal), ICJ Rep. 1991, at 156: "International law, though still an infant science...".

60 ICJ Rep. 1996, at 553.

61 ICJ Rep. 1999, at 181. Author's emphasis.

62 ICJ Rep. 1999, at 194.

63 See, for instance, his very precise analysis of the opening words of the UN Charter in Legality of the Threat or Use of Nuclear Weapons, ICJ Rep. 1996, at 441-442.

64 ICJ Rep. 1996, at 655.
} 
of international society within many of Weeramantry's opinions; and in this development of the globalizing society, international law had a clear constitutive role.

The tension between the sheer might of international relations and the normative constraints of international law, on the one hand, and Weeramantry's belief that the latter must always triumph, on the other, are captured most eloquently in his dissenting opinion in Legality of the Threat or Use of Nuclear Weapons (1996). He notes that:

\begin{abstract}
"The forces ranged against the view of illegality are truly colossal. However, collisions with the colossal have not deterred the law on its upward course towards the concept of the rule of law. It has not flinched from the task of imposing constraints upon physical power when legal principle so demands. It has been by a determined stand against forces that seemed colossal or irresistible that the rule of law has been won." 65
\end{abstract}

Is this idealistic rhetoric? Clearly. Is it realistic assessment of the twentieth century? This is debatable. Is it an affirmation, however, of the importance of the role of law in international politics? Unquestionably so. However, in seeking fully to contextualize this quotation, one should keep in mind that dissimilarly to many of his colleagues on the bench, Weeramantry had a very clear and simple understanding on the question of the legality of nuclear weapons. For him, international law provided a very definitive answer to the issue. As will be noted again later, Weeramantry was convinced that the current law was more than enough to justify his stance against nuclear weapons. However, the case also provided him with the opportunity to assert, more generally, the primacy of law vis-à-vis the threat and use of military force. ${ }^{66}$ Arguments based on political considerations or the realities of international relations could not unseat the fundamental issue of illegality. As he notes in one of his most forthright statements on the matter, "[t]his Court cannot endorse a pattern of security that rests upon terror". ${ }^{67}$ While it has already been suggested that Weeramantry often insisted on the grounding in factual reality of international law, such a contextual approach found its limit when the reality itself was a threat to human society. As he concluded his dissenting opinion in that case, "[n]o issue could be fraught with deeper implications for the human future, and the pulse of the future beats strong in the body of international law". ${ }^{68}$ One might also note the strong intergenerational element to that sentence, considered further below.

If international law is laden with particular values, it is little wonder that Weeramantry considered international adjudication as having a significant role in upholding and promoting a certain vision of international society; the role of the International

65 ICJ Rep. 1996, at 440.

${ }^{66}$ See also Case concerning Legality of Use of Force (Yugoslavia v. Belgium) Request for the Indication of Provisional Measures, ICJ Rep. 1999, at 200: "In a world of legal order based upon the pursuit of peace and peaceful settlement, the message that law can and should be used for avoiding the use of force is one which reverberates with special strength."

${ }_{67}$ ICJ Rep. 1996, at 551.

${ }_{68}$ ICJ Rep. 1996, at 554. 
Court was paramount in this regard. He noted in his separate opinion in Case concerning Sovereignty over Pulau Ligitan and Pulau Sipadan (Indonesia/Malaysia) Application by the Philippines for Permission to Intervene (2001) that "[t]he pre-eminent position of the International Court, situated as it is at the apex of the international judicial structure, attracts special recognition to its pronouncements, even in matters indirectly related to the particular dispute before the Court." ${ }^{69}$ In a similar vein, if more colloquial, was his comment in Case concerning Legality of Use of Force (Yugoslavia v. Belgium) Request for the Indication of Provisional Measures (1991) that "the Court ... [is] the ... upper guardian of the legal norms underpinning the structure of the international community". ${ }^{70}$

If one had to classify what Weeramantry saw as the overarching purposes of the Court, these would undoubtedly be the pacific settlement of disputes, preventing the escalation of conflict, ${ }^{71}$ and the clarification and development of the law. There are too many instances in his opinions of where he has made mention of the judicial function to discuss them comprehensively in this paper. Two particularly contentious aspects of the judicial function, however, may be worth briefly mentioning; the inherent power of the Court to promote peaceful settlement and its ability to clarify the law. On both points, Weeramantry favoured a broad approach to the issue.

As regards his views on the Court's powers of pacific settlement, this can most clearly be seen in Case concerning Legality of Use of Force (Yugoslavia v. Belgium), Request for the Indication of Provisional Measures (1999). Weeramantry, arguably, went further than most of his colleagues when he argued that the Court had an inherent power to assist the respective parties towards the peaceful settlement of its dispute. Although Weeramantry would have indicated certain provisional measures in this particular case, he also argued that the Court's role in this area was not only because of formal inclusion of such authority in its Statute, but rather because the search for peace was intrinsic to the mandate and jurisdiction of a world Court. As he noted, "the Court also has an inherent jurisdiction arising from its judicial function, to lend such assistance as it can towards the process of peaceful settlement."72

69 ICJ Rep. 2001, at 641.

70 ICJ Rep. 1999, at 200.

${ }^{71}$ Of particular note, in this regard, was Weeramantry's dissenting opinion in Case concerning Application of the Convention on the Prevention and Punishment of the Crime of Genocide (Bosnia and Herzegovina v. Yugoslavia (Serbia and Montenegro)) Further Requests for the Indication of Provisional Measures (1993), in which he argued that provisional measures were legally binding, something the Court itself agreed with in LaGrand (Germany v. United States of America) (2001). It should not, however, be presumed that Weeramantry was alone in his opinion in 1993 in arguing that provisional measures should be considered legally binding.

72 Case concerning Legality of Use of Force (Yugoslavia v. Belgium) Request for the Indication of Provisional Measures, ICJ Rep. 1999, at 195. 
While it may be argued that Weeramantry was only drawing explicit attention to that which was already implicit in how the Court had acted, ${ }^{73}$ it is unlikely that the Court as a whole would have subscribed to such a broad view of its jurisdiction. Intriguingly, Weeramantry relied not just on the express purposes of the UN Charter to come to this view, but on what he termed the "time-honoured conception of the judicial function in the world's main forms of civilization and principal legal systems". ${ }^{74}$ This belief in the authority of the Court to act for the greater good was not, however, without its constraints. As will be explored further, below, Weeramantry recognized that there were limitations on what a court of law could do in this area. Nevertheless, within that sizeable zone of discretion, Weeramantry would have sought the greatest possible influence for the Court, particularly in those cases where conflict was ongoing or human rights were threatened. As he noted, speaking about the Court's approach in Legality of the Threat or Use of Nuclear Weapons (1996):

\begin{abstract}
"In that Opinion the Court spoke of the obligation of States to pursue and to conclude negotiations in good faith in regard to nuclear disarmament ... advice which went beyond the traditional scope of an advisory opinion regarding the legality of such weapons. This the Court was clearly entitled to do as an organization functioning within the framework of the United Nations and pursuing the common aim of peace." $" 75$
\end{abstract}

The second aspect of the judicial function that Weeramantry held particularly strong views on was his belief in the Court's ability to clarify and develop the law. ${ }^{76}$ Such clarification, he believed, was a fundamental aspect of its judicial role; its purpose being "an end in itself ... When the law is clear, there is greater chance of compliance than when it is shrouded in obscurity". ${ }^{77}$ Of course, attempts at clarification are often criticized as being nothing more than judge-made law. Weeramantry was acutely aware of such accusations. His defence, rather than simply denying the charge outright, was to be found in the very nature of the task the judiciary was called upon to undertake:

"If the law were all-embracing, self-evident and specifically tailored to cover every situation, the judicial function would be reduced to a merely mechanical application of rules. By very definition, international law is not such a system any more than any domestic system is. Its inherent principles infuse it with vitality, enabling it to

\footnotetext{
73 Though the Court had refused to indicate provisional measures, it did make the following general statement in all ten cases: "whether or not States accept the jurisdiction of the Court, they remain in any event responsible for acts attributable to them that violate international law, including humanitarian law ... in this context the parties should take care not to aggravate or extend the dispute."

${ }^{74}$ ICJ Rep. 1999, at 203.

75 ICJ Rep. 1999, at 198.

76 See n. 37.

77 Legality of the Threat or Use of Nuclear Weapons, ICJ Rep. 1996, at 550.
} 
apply them to new situations as they arise and give them a specificity they lacked before ... The Court is now being invited to exercise its classic judicial function. It is being asked to pronounce whether general principles already existing in the body of international law are comprehensive enough to cover the specific instance. To suggest that this is to invite the Court to legislate is to lose sight of the essence of the judicial function." 78

This is a much more sophisticated argument than simply denying that judge-made law occurs; it highlights both the autonomy of the law and the judicial discretion essential to the Court to enable it to function properly. Of course, much revolves around what one means by "general principles already in existence in the body of international law". As Weeramantry holds a rather expansive view on this question, ${ }^{79}$ incorporating both municipal law analogies and wisdom from religious teaching and past cultures, there is a certain risk of incongruity here. Thus, while Weeramantry is surely right to argue against the "mechanical application of rules", the very significant pool from which he finds such principles arguably militates against his defence of judicial creativity. This, however, raises the broader question as to whether one believes Weeramantry is right to utilize such far-flung principles. While this paper cannot answer that question, it does endeavour to say a little more on it later.

Of central importance for Weeramantry is the position of the Court as the principal judicial organ of the United Nations, ${ }^{80}$ thus forming both a conceptual bond between the purposes of UN and the judicial function of the Court and, institutionally, between the Court and what he referred to as the wider "United Nations family". 81 In his dissent in Legality of the Use by a State of Nuclear Weapons in Armed Conflict (1996) in which the World Health Organization's request for an advisory opinion had been turned down by the Court on the grounds of lack of competence to request an opinion on such a matter, Weeramantry felt duty bound to disagree. As he noted, "[i]t is not a Court existing outside the United Nations system, but one functioning from within. It is in a state of harmonious co-existence and co-operation with the other organs of the Organization in their common goal of the attainment of world peace and the high ideals set before them all by the United Nations Charter." 82 Although the link between the Court and the UN, particularly in relation to its advisory function, had long been recognized by the Court; ${ }^{83}$ what Weeramantry arguably has done is to supplement this with a richer and more explicit understanding

${ }^{78}$ Legality of the Use by a State of Nuclear Weapons in Armed Conflict, ICJ Rep. 1996, at 164-165.

79 See, for instance, Case concerning East Timor (Portugal v. Australia), ICJ Rep. 1995, at 211:

"The dependence of international law for its development and effectiveness on principles, norms and standards needs no elaboration."

${ }^{80}$ Article 92, UN Charter and article 1, Statute of the Court.

${ }^{81}$ Legality of the Use by a State of Nuclear Weapons in Armed Conflict, ICJ Rep. 1996, at 167.

82 Idem.

83 See Interpretation of Peace Treaties with Bulgaria, Hungary and Romania, ICJ Rep. 1950, at 71: "the reply of the Court, itself an 'organ of the United Nations', represents its participation in the activities of the Organization and, in principle, should not be refused." 
of the links between the UN Charter and the normative values underpinning the Court's work. ${ }^{84}$

If this is somewhat novel, it is certainly not particularly controversial. Contrast that with Weeramantry's views on the relationship between the Court and the Security Council: the issue as to the precise relationship between their respective roles, and in particular whether the Court could act, even when the Security Council had already done so, was considered in detail by a number of judges, particularly in the Cases concerning Questions of Interpretation and Application of the 1971 Montreal Convention arising from the Aerial Incident at Lockerbie, Request for the Indication of Provisional Measures (1992). Weeramantry's opinion was, probably unsurprisingly, one of the most strident in asserting the role of the Court. While agreeing that a Security Council resolution adopted under Chapter VII "must be treated as binding on Libya as on all countries", he did not, unlike the majority, feel that this either prohibited or "render[ed] it inappropriate" to indicate provisional measures. ${ }^{85}$ Although rather tentative in his reasoning and wording, Weeramantry was nevertheless clearly not overly deferential. ${ }^{86}$ In fact, by asserting the role of law in resolving international conflict, ${ }^{87}$ he placed the Court on parity with the Security Council. ${ }^{88}$

In his dissenting opinion in Legality of the Threat or Use of Nuclear Weapons (1996), Weeramantry went much further by noting that:

"[E]ven if the Security Council had expressly endorsed the use of such weapons, it is this Court which is the ultimate authority on questions of legality, and ... such an observation, even if made, would not prevent the Court from making its independent pronouncement on this matter". 89

${ }^{84}$ See, for instance, Case concerning Legality of Use of Force (Yugoslavia v. Belgium) Request for the Indication of Provisional Measures, ICJ Rep. 1999, at 203: "[requiring the Court to promote peaceful settlement] dovetails into the principle of peaceful resolution of disputes already referred to as a cornerstone of the United Nations Charter and the Statute of the International Court of Justice."

85 See, for instance, Case concerning Questions of Interpretation and Application of the 1971 Montreal Convention arising from the Aerial Incident at Lockerbie (Libyan Arab Jamahiriya v. United Kingdom) Request for the Indication of Provisional Measures, ICJ Rep. 1992, at 50.

${ }^{86}$ ICJ Rep. 1992, at 69: "As with its failure to consider the Montreal Convention, so also resolution 731 (1992) fails to consider this well-established principle of international law." He is referring to the principle of aut dedere aut judicare.

${ }^{87}$ ICJ Rep. 1992, at 70: "A great judge once observed that the laws are not silent amidst the clash of arms. In our age we need also to assert that the laws are not powerless to prevent the clash of arms."

${ }^{88}$ Idem: "But in areas not covered by its binding decisions under Chapter VII, the Court is free to use its influence and authority to serve the purposes of international peace in which it has as much an interest as any organ of the United Nations." Emphasis added.

${ }^{89}$ ICJ Rep. 1996, at 519. 
Although clearly obiter, both the tenor of this statement and the implications thereof go significantly beyond the views of other judges, both past and present. ${ }^{90}$ Weeramantry clearly sees the Court as a constitutional court, endowed with ultimate authority on matters of law. This is a courageous position to hold in light of the current power relationships within the United Nations.

Beyond this important - if rather narrow and somewhat speculative - issue, Weeramantry also sought to ensure a broad understanding of the jurisdiction of the Court. It has already been noted that Weeramantry believed that basic notions of fairness should, in exceptional cases, preclude the Court from exercising jurisdiction in a particular case, yet his general approach was to find jurisdiction, whenever that was possible. As he noted in his dissent in Case concerning East Timor (Portugal v. Australia) (1995), in which Australia argued - and the Court concurred - that it should not exercise jurisdiction because of the absence of a necessary third party, viz., Indonesia on the basis of the Monetary Gold (1954) principle, "[i]t is an important circumstance relating to all jurisdictional questions that this Court is the international system's place of ultimate resort for upholding the principles of international law, when all other instrumentalities fail". ${ }^{91}$ Thus, he rejected, as an anathema to this judicial mandate, any interpretation of the Court's jurisdiction that unduly narrowed its scope and remit. ${ }^{92}$ Moreover, as regards the argument that Indonesia's interests may well be affected, he suggested - relying, in part, on general juridical principle - that this was no barrier to jurisdiction and that such effects on third States are "manifesting themselves increasingly as the world contracts into a more closely interknit community." "93 Weeramantry's resolute dissent in this case, alone but for judge ad hoc Skubiszewski, also indicates both his willingness to voice an unpopular opinion and his determination to stand up for his understanding of the Court's jurisdiction. ${ }^{94}$

90 See the separate opinion of Judge Lachs in Case concerning Questions of Interpretation and Application of the 1971 Montreal Convention arising from the Aerial Incident at Lockerbie (Libyan Arab Jamahiriya v. United States of America), ICJ Rep. 1992, at 138: "[the Court] is the guardian of legality for the international community as a whole, both within and without the United Nations. One may therefore legitimately suppose that the intention of the founders was not to encourage a blinkered parallelism of functions but a fruitful interaction." Weeramantry quoted this in Case concerning East Timor (Portugal v. Australia), ICJ Rep. 1995, at 220.

91 ICJ Rep. 1995, at 161. Emphasis added.

92 ICJ Rep. 1995, at 155: "the substantive and procedural principles governing this court's jurisdiction cannot operate so restrictively."

93 Idem. See also Case concerning Sovereignty over Pulau Ligitan and Pulau Sipadan (Indonesia/Malaysia) Application by the Philippines for Permission to Intervene, ICJ Rep. 2001, at 630, separate opinion: "The closely interknit global society of tomorrow will see a more immediate impact upon all States of relations of transactions between any of them, thus enhancing the practical importance of this branch of procedural law."

${ }^{94}$ Falk, n. 8, at 18: "In each of the three prominent legal controversies presented to the World Court during his tenure, Weeramantry, unlike the majority of his brethren refuses to strike what appears to be a tacit Faustian bargain with geopolitics, either in the form of a compromise that significantly defers to the practice of leading states, as in the majority opinion in Nuclear Weapons case, or by outright deference to the priorities of those political actors with predominant power and wealth, 
A similarly reasoned approach to jurisdiction can be seen in his dissent in Fisheries Jurisdiction Case (Spain v. Canada) Jurisdiction of the Court (1998), which involved a Canadian reservation to its declaration under the optional clause scheme. For the majority, the reservation must be given effect as a manifestation of Canadian sovereignty, thus depriving the Court of jurisdiction in this particular instance. Weeramantry disagreed. He felt that within the jurisdiction granted to the Court by the existence of optional clauses between the parties a "haven of legality" existed. ${ }^{55}$ As he argues, "[o]nce a State has entered the consensual system, submission to the basic rules of international law inevitably follows." 96 Not denying that a State could make reservations to its declaration, Weeramantry was nevertheless of the opinion that "the interests of justice are best served by taking a broader view where that is consistent with the terms of the declaration". ${ }^{97}$ Moreover, as with East Timor, his support for the Court's jurisdiction was not simply for its own sake, but to ensure the Court played an ever fuller part in upholding the rule of law within the international community. As he notes,

"The progressive contraction of that jurisdiction which could result could weaken
the prospects for its continuing development ... if the long and difficult road towards
the goal of judicial settlement of international disputes is to be made easier, each
stop along the way must offer the maximum judicial shelter it can provide."98

For Weeramantry, this ideal was all-important. It was for him a matter of judicial policy that international law and the International Court should constantly be progressing towards greater influence and authority. As will further be explored in the next part, Weeramantry believed that one of the principal functions of the international judge was to promote this constant evolution in the rule of law.

\subsection{Weeramantry's Grotian quest?}

It comes as little surprise that one of the themes underlying Weeramantry's time at the Court was his attempt to progress the law beyond its current state. There was in most of his opinions a degree of idealism as to what international law could become, particularly if released from the strictures of present-day global politics. In his clearest expression of this belief, Weeramantry associated himself with the

as seems arguably to occur in Lockerbie and East Timor decisions." For information, Weeramantry was in fact in a minority of one on only one occasion, namely, his dissent in Case concerning Application of the Convention on the Prevention and Punishment of the Crime of Genocide (Bosnia and Herzegovina v. Yugoslavia) Counter-Claims (1997).

95 ICJ Rep. 1998, at 501.

96 ICJ Rep. 1998, at 500.

97 ICJ Rep. 1998, at 512.

98 ICJ Rep. 1998, at 513-514. 
view that "international law has clearly a commitment to the Grotian vision": 99 a global society governed by the rule of law. Both as judge and as academic, he focused upon the possibilities of international law and global institutions, rather than their limitations. ${ }^{100}$ Of course, he was not the first judge of the International Court to foresee where international law might go, ${ }^{101}$ although his opinions are undoubtedly some of the most wide-ranging and detailed on these issues. As Falk notes,

"What sets Judge Weeramantry apart among international law specialists is his deep
belief that these goals [of 'human survival in social and political conditions of
harmony, dignity, and tolerance'] are not only integral to cultural identity, but have
been long inscribed in the deep structures of international law, which prefigures a
beneficial future for humanity as contrasted with the Hobbesian sense of fundamental
antagonism and struggle as the permanent reality of the human condition...". ${ }^{102}$

Again, it is impossible to provide a comprehensive account of Weeramantry's opinions in this regard. Rather, two areas are briefly discussed; first, his attempt to entrench, more firmly within the international system, a global order clearly based on law and secondly, his contribution to the establishment of a new discrete area of international law, viz., environmental law. This part will then conclude with an assessment of Weeramantry's approach and the inherent tension that undoubtedly exists with the formation of such views whilst a judge, and considers whether he has transgressed the positivist limitations of the judicial mould.

One of the most notable aspects in Weeramantry's opinions was his support for the United Nations Charter and the work of the UN Organization. As the most complete manifestation of internationalism that currently exists, Weeramantry considered it a necessary part of his judicial role to defend the purposes of the UN and to promote its objectives. He noted in Legality of the Use by a State of Nuclear Weapons in Armed Conflict (1996) that "[t]he family of United Nations agencies, in working harmoniously for the common welfare of the global community, will need to work as a team". ${ }^{103}$ Similarly, in his separate opinion in Difference relating to Immunity from Legal Process of a Special Rapporteur of the Commission on Human Rights (1999), he emphasized the importance of moving towards a universally applicable system of protection for UN personnel. As noted in the previous part, it was also the unique position of the Court within the UN system that Weeramantry believed provided it with the necessary mandate actively to support international law

\footnotetext{
99 Legality of the Threat or Use of Nuclear Weapons, ICJ Rep. 1996, at 551.

100 See the draft UN Declaration of Scientific Responsibility in Relation to Nuclear Weaponry which he devised and sent to every diplomatic mission at the UN (text found in C. Weeramantry, Nuclear Weapons and Scientific Responsibility, 1987).

101 See, for instance, Fisheries Case (United Kingdom v. Norway), ICJ Rep. 1951, at 149, individual opinion per Judge Alvarez: "the law of social interdependence is taking the place of the old individualistic law." Author's emphasis.

${ }^{102}$ Falk, n. 8, at 16. The attendant issues of legal reasoning are dealt with in the next part.

103 ICJ Rep. 1996, at 170.
} 
within the Organization's affairs. He may have been too audacious in conceiving of the Court as a constitutional tribunal, analogous to a domestic supreme court, yet his view that the Court should be playing a broader role within the business of the Organization reflected a firm belief in the global moral, as well as the legal and political, imperative of the United Nations.

Moreover, beyond the strict confines of the UN Organization, Weeramantry also sought to ensure a more legal, rights-orientated framework for the international community. His arguments in favour of automatic succession of the Genocide Convention and his willingness to grant Portugal locus standi to enforce its rights of trusteeship over East Timor against Australia both stand as good examples of this wider approach. They also underlined his belief that international law should always be ready to intervene to protect the weak and those without a voice. As can be seen from his understanding of the notion of self-determination: "Charter principles combine with well-established fiduciary principles and principles of tutelage to underline the paramount importance of the interests of the non-self-governing territory over all other interests. That priority of interest is not easily defeated ... and [it is] the function of international law to ensure its protection." 104 Moreover, this belief in the universal nature of the international legal system also led him to the view that, whilst there may be certain in-built structural inequalities within international society, even within international law itself, this was not something that should be either supported or condoned by the International Court. ${ }^{105}$

One can also see Weeramantry's attempt to promote the integrity of international law in his dissenting opinion in Legality of the Threat or Use of Nuclear Weapons (1996). In particular, in affirming the overarching relevance of the Martens Clause to international humanitarian law, ${ }^{106}$ Weeramantry relied upon the laws of humanity and the dictates of the public conscience to demonstrate the "stark" incompatibility of nuclear weapons with these fundamental precepts. ${ }^{107}$ Mendlovitz and Datan see Weeramantry's dissent as a significant move away from the current affection of law for established political structures. They note, "[j] ust as Grotius first saw in the laws of war and peace the emergence of the nation-state system and state sovereignty, so Weeramantry is foreshadowing a globalization which moves the state system from

\footnotetext{
104 ICJ Rep. 1995, at 192.

105 Legality of the Threat or Use of Nuclear Weapons, ICJ Rep. 1996, at 528: "If the corpus of international law is to retain the authority it needs to discharge its manifold and beneficent functions in the international community, every element in its composition should be capable of being tested at the anvil of equality."

106 First adopted at the 1899 Hague Peace Conference, and utilized in subsequent texts, it states that "[u]ntil a more complete code of the laws of war has been issued, the High Contracting parties deem it expedient to declare that, in cases not included in the Regulations adopted by them, the inhabitants and the belligerents remain under the protection and the rule of the principles of the law of nations, as they result from the usages established among civilised peoples, from the laws of humanity, and the dictates of the public conscience."

107 ICJ Rep. 1996, at 489.
} 
geopolitics to humane governance."108 They go on to define humane governance as "a type of geo-governance that is people- and human rights-centred rather than statist and market-centred. The guiding principles of humane governance ... include economic well-being, social justice, non-violence, ecological stability, and positive identity." 109 One can immediately recognize these guiding principles as characteristic of Weeramantry's universal understanding of international law.

Moving beyond nuclear weapons, it is also no surprise that in this redefining of global norms Weeramantry has also been very interested in environmental considerations. ${ }^{110}$ Weeramantry has taken a lead in the Court on matters of environmental protection. He first raised environmental issues in his separate opinion in Case concerning Maritime Delimitation in the Area between Greenland and Jan Mayen (Denmark v. Norway) (1993); as he noted, "[n]otions of ... the sacrosanct nature of earth resources, harmony of human activity with the environment, respect for the rights of future generations, and the custody of earth resources with the standard of due diligence expected of a trustee are equitable principles stressed by those traditions"(sic). ${ }^{111}$ This concern for the identification and progressive elaboration of environmental principles was then taken significantly further in various later opinions. Although this was undoubtedly a relatively new area of international law, Weeramantry was determined to illuminate fully its legal implications for the international community and, equally important, for the Court. Of particular regard was his view that " $[\mathrm{t}]$ here is a State obligation lying upon every member State of the community of nations to protect the environment, not merely in the negative sense of refraining from causing harm, but in the positive sense of contributing affirmatively to the improvement of the environment." 112 He took this further in Case Concerning Gabčikovo-Nagymaros Project (Hungary/Slovakia) (1997), by examining in detail the concept of sustainable development and finding it to be not merely a principle of customary international law, but "one of the most ancient of ideas in the human heritage". 113

For Weeramantry, environmental concerns present the international community with a unique challenge, which demand a legal system that is adaptable to this new state of affairs. As he noted in Case concerning Kasikili/Sedudu Island (Botswana/Namibia) (1999),

"The future will demand an international law that is sensitive and responsive to the problems of environmental law ... The principles and the duties arising from environmental obligations now superimpose themselves upon such rights arising from State

\footnotetext{
108 Mendlovitz, S. and Datan, M., "Judge Weeramantry's Grotian Quest”, 7 Transnational Law and Contemporary Problems (1997), at 415.

109 Ibid., at 413.

110 A further paper on Weeramantry's understanding on environmental law is currently under preparation.

111 ICJ Rep. 1993, at 276-277.

112 ICJ Rep. 1996, at 141. Emphasis added.

113 ICJ Rep. 1997, at 110.
} 
sovereignty as may have been recognized by prior international law in an absolutist form." $" 114$

The cross-cutting nature of environmental considerations and their lack of respect for national boundaries simply affirmed their global importance. Moreover, Weeramantry was heavily influenced by the work of Professor Brown Weiss and her notion of the intergenerational rights of generations yet to be born. ${ }^{115} \mathrm{He}$ succinctly notes that "[i]n a matter of which it is duly seised, this Court must regard itself as a trustee of those rights in the sense that a domestic court is a trustee of the interests of an infant unable to speak for itself." 116 In seeking relevant legal principles to tackle these new challenges, Weeramantry has taken great assistance from past cultures; in fact, it is in some of his "environmental" opinions that his reliance on past wisdom was most pronounced. One can contrast that with the Court's much more restrained approach. Weeramantry was clearly frustrated by the reluctance of the Court as a whole to consider in any meaningful way the challenges of environmental degradation. In what was arguably his most vociferous outburst in an individual opinion, he concluded his dissent in Request for an Examination of the Situation (1995) with the comment: "[t]he Court has too long been silent on these issues and, in the words of ancient wisdom, one may well ask 'If not now, when?'."117

The range of topics on which Weeramantry had the opportunity to comment upon makes it difficult to come to any definite assessment of the validity of his views. In any event, this can only be a partial analysis because - as has been noted upon numerous times before - the connexions he makes between the substantive law and his method of legal reasoning prevent any real conclusions from being drawn until his approach to this issue has also been examined. Nevertheless, there are certain comments that can be made. For some, Weeramantry's appreciation - in contrast to that of his contemporaries - of what law can achieve is little short of invigorating. As Mendlovitz and Datan note, in relation to his dissent on the question of nuclear weapons, “[u]nlike the 'majority' opinion, Judge Weeramantry is not trapped between the past and the spectrum of potential power structures. Instead, he discerns the signs of humane governance tomorrow already manifest in the legal and political structures of today." 118

Others are more circumspect. Falk, who so positively described Weeramantry's time on the bench (and from which I derived the notion of a "heroic undertaking"), is ultimately more balanced in his final assessment. Again as regards the particular issue of nuclear weapons, Falk rejects Weeramantry's view because "the unmediated

\footnotetext{
114 ICJ Rep. 1999, at 1195.

115 Brown Weiss, E., In Fairness to Future Generations: International Law, Common Patrimony and Intergenerational Equity (Tokyo: UNU Press, 1989).

116 Request for an Examination of the Situation, ICJ Rep. 1995, at 341.

117 ICJ Rep. 1995, at 362. Since then, the Court has begun actively to consider environmental arguments in Legality of the Threat or Use of Nuclear Weapons (1996) and Case Concerning Gabčikovo-Nagymaros Project (Hungary/Slovakia) (1997).

118 Mendlovitz and Datan, n. 108, at 427.
} 
analysis of applicable legal principles assumes an unrealistic autonomy for the domain of law and an implausible objectivity of interpretation on the part of the policymaker or judicial official." 119 On a more pragmatic note, Falk thinks that global disarmament "can only be usefully achieved on the basis of an agreement that is endorsed by the nuclear weapons states." 120 This contrasts with Weeramantry's view that a defiant declaration of law against such nuclear weapons will provide a powerful foundation against which even the most powerful States will ultimately find hard to resist.

It should not, however, be considered that Weeramantry is naif to think a judgment from the Court is all that it will take; rather, he believes "[i]t will assist in building up a climate of opinion in which law is respected."121 This is a crucial difference. Thus, while Weeramantry may be criticized, in some cases, for too readily supporting the "unrealistic autonomy for the domain of law" - not only as regards nuclear weapons, but more broadly (one can refer back to Weeramantry's attempt to conceptualize the International Court as a constitutional tribunal) - this is not the same as to suggest that he is blind to the political landscape in which the Court operates. Rather, he views the role of the Court as providing authoritative judgment and normative guidance within the context of an international system still largely controlled by, and governed on the basis of, political strength. ${ }^{122}$ International law and the International Court are, however, not the handmaidens of any political elite; for Weeramantry, its political neutrality and its normative aspirations combine to provide the foundations of a legal order suited to an emerging, greatly more integrated, international society. Although Weeramantry's views are still open to criticism in this regard - in Falk's opinion, largely because they are ultimately ineffective in promoting substantive change ${ }^{123}$ - Weeramantry's opinions are nevertheless significant in affirming the important role jurists can and should play in continually striving towards an international society based on legal rules even if, at present, he appears something of a "voice in the wilderness".

Of course, as an academic Weeramantry could make such statements without fear of censure. As a judge, though, could he act with the same degree of latitude? The conception of the judge is always that s/he acts "within the law". As already noted, Weeramantry resolutely denied judicial law-making yet, equally, his response left significant space for judicial creativity. Nevertheless, in Legality of the Threat or Use of Nuclear Weapons (1996), he continually asserted his conviction that he

\footnotetext{
119 Falk, n. 8, at 26.

120 Idem.

121 ICJ Rep. 1996, at 550.

122 Case concerning East Timor (Portugal v. Australia), ICJ Rep. 1995 220: "A matter for adjudication under the judicial function of the Court within its proper sphere of competence is not to be considered extraneous to the Court's concerns merely because political results may flow from it. 123 Although not saying so directly, there is also the implication in Falk's paper that Weeramantry suffers from the utopianism captured by Koskenniemi in From Apology to Utopia (1989). As Falk notes, he is "setting forth legalistic positions that are dismissed as pathetic fantasy by those entrusted with the responsibilities of political leadership." (see n. 8, at 32).
} 
was deciding the issue on the basis of lex lata ${ }^{124}$ recognition both of his judicial role and the reality that greater weight would be given to an opinion that asserted the law "as it now is". ${ }^{25}$ However, both in substance and tone, Weeramantry's approach to positivist legal thought stretches the very nature of this paradigm. In particular, although respectful of the essential constraints inherent within international law and international adjudication and, respectively, the notions of sovereignty and consent, Weeramantry has never been prepared to endorse understandings that circumscribed his ability to develop the law. Mention has already been made of Weeramantry's approach to the question of consent in matters of jurisdiction in such cases as Fisheries Jurisdiction Case (Spain v. Canada) (1998). On issues of substantive law, he was equally firm. He noted in Legality of the Threat or Use of Nuclear Weapons (1996) that:

\begin{abstract}
"The doctrine that the sovereign is free to do whatever statute does not expressly prohibit is a long-exploded doctrine. Such extreme positivism in legal doctrine has led humanity to some of its worst excesses. History has demonstrated that power, unrestrained by principle, becomes power abused. Black-letter formulations have their value, but by no stretch of the imagination can they represent the totality of the law.",126
\end{abstract}

There is no disguising the gulf between positivism stricto sensu and Weeramantry's understanding thereof. For Weeramantry, however, there is no contradiction. In fact, one is reminded of Philip Allott's comment that "[1]aw constrains or it is a travesty to call it law. Law enters decisively into the willing of its subjects or it is a travesty to call it law. Law transcends the power of the powerful and transforms the situation of the weak or it is a travesty to call it law."127 Others have referred to his approach as importing into "positive international law a strong set of naturalist tendencies." 128 There is no denying this is a source of tension yet for Weeramantry this is not the traditional tension between the "is" and the "ought", but between international law as narrowly restrained by the confines of formalistic Western legal thought, on the one hand, and his own understanding, not bound by such an artificial enclosure, on the other.

\footnotetext{
124 ICJ Rep. 1996, at 440.

125 ICJ Rep. 1996, at 439.

126 ICJ Rep. 1996, at 494. See also Request for an Examination of the Situation, ICJ Rep. 1995, at 360 , dissenting opinion: "Black-letter law and legal logic do not assist us when we reach a fork in the road".

127 Allott, P., Eunomia: A New Order for a New World (Oxford: Oxford University Press, 1990), at $\mathrm{x}$ vii.

${ }^{128}$ Falk, n. 8, at 17. See also Weeramantry's discussion of Hart's minimum content of natural law in Legality of the Threat or Use of Nuclear Weapons, ICJ Rep. 1996, at 520-521. As Weeramantry notes, "[h]ere is a recognized minimum accepted by positivistic jurisprudence which questions some of the more literal assumptions of other schools."
} 


\subsection{A new model of reasoning?}

Weeramantry's understanding of international law is, therefore, clearly built around a more universal approach to legal reasoning. For Weeramantry, this was not an arbitrary choice of methodology, but one mandated by the very structure and position of the International Court. As the principal judicial organ of the United Nations, its Statute requires diversity of law in all its forms to be represented on the Court. ${ }^{129}$ As Weeramantry, paraphrasing the relevant provision, noted in his dissent in Case concerning Legality of Use of Force (Yugoslavia v. Belgium) Request for the Indication of Provisional Measures (1999), "the International Court of Justice, constituted as it is to embody the representation of the main forms of civilization and of the principal legal systems of the world, is heir to the judicial traditions of many civilizations." $" 130$

Where such diversity of membership is arguably most relevant, if not absolutely vital, is when the International Court seeks to rely upon "general principles of law recognised by civilised nations" as mandated under article 38.1(c) of its Statute. Although it is perfectly possible for the Court to consider such notions in the abstract, judges with some appreciation of how general principles are understood and applied at the regional, national and/or local levels are surely a significant asset to the judicial bench. Weeramantry has had much to say about the importance of a universal court and, in particular, how this reference to general principles of law should provide a significant indication to the International Court as to how it should approach and interpret international law. As he has noted since leaving the Court,

\footnotetext{
"Since international law specifically includes 'the general principles of law recognized by civilized nations' a heavy burden is thrown upon international lawyers and judges to ascertain what these are and not to form their conclusions on a survey of only part of the field. The great familiarity with other systems ... will facilitate a search for those general principles - a search which is often only a partial search under prevailing circumstances." 131
}

Weeramantry clearly conceptualizes the role of the International Court broadly; one senses that for him the judicial authority of the Court is not just derived from the formal sources of the UN Charter and its Statute, but that, on a more fundamental level, it is because the Court represents, and is at the apex of safeguarding, the "main forms of civilization". As he noted in his separate opinion in Case concerning Maritime Delimitation in the Area between Greenland and Jan Mayen (Denmark v. Norway) (1993), "[t]he International Court of Justice ... is under a particular

\footnotetext{
129 Article 9, Statute of the Court.

130 ICJ Rep. 1999, at 198. Footnote removed. See also Case Concerning Gabčíkovo-Nagymaros Project (Hungary/Slovakia), ICJ Rep. 1997, at 109: "this Court constitutes a unique forum for the reflection and the revitalization of those global legal traditions".

131 See Weeramantry, C., Universalising International Law (Leiden/Boston: Martinus Nijhoff Publishers, 2004), at 30.
} 
obligation to search in all these traditions and legal systems for principles and approaches that enrich the law it administers." 132 Moreover, he sought to affirm not only the significance of the world's principal legal systems in the jurisprudence of the Court, but also to incorporate other normative frameworks, gleaned from, inter alia, religious beliefs and customary practices developed throughout the ages, whenever relevant. ${ }^{133} \mathrm{He}$ does this not for its own sake, but because international law is, he argues, immensely strengthened thereby. ${ }^{134}$

In his clearest defence of the use of material, i.e., his separate opinion in Case Concerning Gabčikovo-Nagymaros Project (Hungary/Slovakia) (1997), Weeramantry very firmly sought to place his approach within mainstream international law. First, as already noted, the inclusion of traditional wisdom is explicitly mandated by the Statute of the Court itself. ${ }^{135}$ Second, it is, Weeramantry believes, in accord with traditional understandings of legal reasoning. ${ }^{136}$ Third, it reflects the historic approach of Grotius to the development of international law. ${ }^{137}$ Fourth, the settlement of present-day disputes undoubtedly benefits, he argues, from such wisdom. ${ }^{138}$ Fifth, international law, more generally, profits from a richer and more complete understanding of "all the insights available from the human experience." ${ }^{139}$ Finally, sixth, the very authority of the Court is jeopardized, he feels, if it fails to take this

132 ICJ Rep. 1993, at 273-4.

133 On this basis, one suspects that Weeramantry might object to the more State-centric definition of general principles to be found in the 1998 Statute of the International Criminal Court, "general principles of law derived by the Court from national laws of legal systems of the world." (article 21(1)(c), ICC Statute).

134 ICJ Rep. 1993, 278: "Such transcending qualities, as visualized by those systems, add new dimensions to the equitable framework within which the equities of the law of the sea can evolve, and add authority to this structure." (emphases added).

135 ICJ Rep. 1997, at 109-110: "when the Statute of the Court described the sources of international law as including the 'general principles of law recognized by civilized nations', it expressly opened the door to the entry of such principles into modern international law."

136 ICJ Rep. 1997, at 96: "In drawing into international law the benefits of the insights available from other cultures, and in looking to the past for inspiration, international environmental law would not be departing from the traditional methods of international law."

137 Idem: "Rather than laying down a set of principles a priori for the new discipline of international law, he sought them also a posteriori from the experience of the past, searching through the whole range of cultures available to him for this purpose."

138 ICJ Rep. 1997, at 97: "I see the Court as being charged with a duty to draw upon the wisdom of the world's several civilizations, where such a course can enrich its insights into the matter before it."

139 ICJ Rep. 1997, at 119. Weeramantry relied in part on Sir Robert Jennings, a one-time president of the Court who, writing extra-judicially, argued that "[i]t seems to the writer ... that at the present juncture in the development of the international legal system it may be more important to stress the imperative need to develop international law to comprehend within itself the rich diversity of cultures, civilizations and legal traditions." (R. Jennings, "Universal international law in a multicultural world' in TMC Asser Institute (ed.), International Law and the Grotian Heritage, 1985). 
opportunity to utilize a broader range of sources. ${ }^{140}$ This last point is all the more pertinent, for Weeramantry, in the light of the universal nature of the International Court and the civilizations which its Statute so clearly states it must reflect.

The sheer diversity of traditional practices, philosophical thought, and religious teachings upon which Weeramantry relies are beyond brief description. In Case Concerning Gabčikovo-Nagymaros Project (Hungary/Slovakia) (1997), for instance, Weeramantry highlights various examples of traditional irrigational practices including in his native Sri Lanka, China, Iran, and sub-Saharan Africa, all of which he believed reconciled environmental and development considerations so effectively that they "carry a message to our age". ${ }^{141}$ He then, in the same opinion, undertook a more general survey of the spiritual and philosophical teachings to have shown respect for the environment over the centuries. This included consideration of the belief systems of Native Americans, Africans, Pacific Islanders, Aborigines, and ancient Indians, as well as the teachings of Islam and the romanticism of European literature. In the same case, he also manages to incorporate references to The Mahavamsa (the ancient chronicle of Sri Lanka), Milton's Paradise Regained, and the writings of Arthur C. Clarke!

The key to appreciating why Weeramantry so widely conceptualizes legal reasoning is to be found in his understanding of the relationship between society and law. He notes: "[ $t$ ]he ingrained values of any civilization are the source from which its legal concepts derive, and the ultimate yardstick and touchstone of their validity". ${ }^{142}$ In his earlier opinion in Legality of the Threat or Use of Nuclear Weapons (1996), he had made a very similar point when discussing the necessity of understanding the cultural context of the rules that regulate warfare:

\begin{abstract}
"It greatly strengthens the concept of humanitarian laws of war to note that this is not a recent invention ... it is deep-rooted in many cultures - Hindu, Buddhist, Chinese, Christian, Islamic and traditional African ... The multicultural traditions that exist on this important matter cannot be ignored in the Court's consideration of this question, for to do so would be to deprive its conclusions of that plenitude of universal authority which is available to give it added strength - the strength resulting from the depth of the tradition's historical roots and the width of its geographical spread." 143
\end{abstract}

At a certain level of abstraction, Weeramantry's approach is difficult to criticize. The finding and endorsing of universal values as gleaned from cultures throughout the ages and from around the globe to "strengthen" international law are commendable. However, his approach is not without its flaws. Three principal criticisms may be levelled. First, although Weeramantry's universalism clearly does not seek to

\footnotetext{
140 ICJ Rep. 1997, at 97: "The Court cannot afford to be monocultural, especially where it is entering newly developing areas of law."

141 ICJ Rep. 1997, at 98.

142 ICJ Rep. 1997, at 108.

143 ICJ Rep. 1996, at 478.
} 
homogenize the cultures upon which he relies - there is a clear sense of respect and deference in his use of such practices and principles - his understanding of universalism and his rather random selection of historical and religious examples runs the risk of over-simplifying what are inevitably much more complex historical episodes and belief-structures. Related to this, secondly, is his belief that civilizations share certain common and inherently positive values. Not only is this, it is argued, not necessarily correct; it ignores very real cultural differences between societies. ${ }^{144}$ Thirdly, it is unclear what role Weeramantry is giving to this wisdom within his legal reasoning process. Although he expressly relies on the notion of general principles of law as permitted under article 38.1(c) of the Court's Statute to incorporate such teachings, he is careful not to establish a current substantive obligation solely on the basis of historical wisdom. Nevertheless, not only is the line between past experience and present law somewhat confused $;{ }^{145}$ what is also unclear is the jurisprudential weight that Weeramantry gives to such material in his reasoning. ${ }^{146}$ As he notes, "[t]his is a legitimate source for the enrichment of international law, which source is perhaps not used to the extent which its importance warrants". ${ }^{147}$ The difficulty, however, is that what "enrichment" actually means is an inherently open and ambiguous concept. Where are the limits of, and what is permissible in the use of, such material? While Weeramantry himself has a clear understanding of how to extract such evidence from history, ${ }^{148}$ this is inevitably a somewhat subjective process.

\section{CONCLUSION}

How, then, might one evaluate Weeramantry's time as a judge on the bench of the International Court? It is surely impossible to measure a judicial career by reference to managerial notions such as success and effectiveness. Even with his very long list of dissenting opinions, it would be ridiculous to conclude that Weer-

\footnotetext{
144 Falk, n. 8, at 21: "In its more moderate formulation, a pluralist view of civilizational identity argues that there are notable divergencies on matters of values and beliefs, as well as with respect to historical experience, that subverts, or at the very least, qualifies claims of a universal normative order."

145 In Case Concerning Gabčikovo-Nagymaros Project (Hungary/Slovakia) (1997), he goes on to discuss "living law" - "compliance with which is so axiomatic that it is taken for granted, is not deprived of the character of law by the extraneous test and standard of reduction to writing." (ICJ Rep. 1997, at 109). As living law can be incorporated into international law as a "general principle of law", one might criticize Weeramantry for, arguably, opening up this Pandora's Box even further." 146 ICJ Rep. 1997, at 103: "The task of the law is to convert such wisdom into practical terms." 147 ICJ Rep. 1997, at 96.

148 Legality of the Threat or Use of Nuclear Weapons, ICJ Rep. 1996 439: "It requires the Court to scrutinize every available source of international law, quarrying deep, if necessary, into its very bedrock. Seams of untold strength and richness lie therein, waiting to be quarried. Do these sources contain principles mightier than might alone, wherewith to govern the mightiest weapon of destruction yet devised?" Emphasis added.
} 
amantry was unsuccessful as a judge. Nevertheless, if one were to ask whether Weeramantry achieved what he himself set out to achieve (as he said in his own words, "some suggestions which, though I am in a minority, may still, I hope, be of some utility"149), one would be forced to concede that, at the present time, the majority of his views have failed to permeate the jurisprudence of Court as a whole. ${ }^{150}$ The bench remains distinctly traditionalist both in terms of its outlook and its legal reasoning; critics would suggest that it was Weeramantry himself who was out of step: out of step with the political realities of the international judicial function. His writings may be less a heroic undertaking and more a misconceived endeavour.

Nevertheless, even if one was minded to agree with this point of view, it would be wrong to marginalize or malign Weeramantry's contribution as simply the work of a legal maverick. Moreover, if one were obliged to classify his contribution both to international law and the International Court, one might say it was three-fold: first, he left the Court with a legacy of stimulating, challenging, and highly reasoned separate and dissenting opinions on a diverse range of topics. Second, the Court would be neglectful if it were to ignore his consistent and vocal reminder that it should always adjudicate with fairness, without fear or favour, and in support of the rule of law. Third, his emphasis on the universal nature of the Court, moving away from the "cultural and disciplinary boundaries which have traditionally hemmed in the discipline of international law" "151 towards a jurisprudence that embraces the diversity of cultures from which it could derive insight and clarification (although seemingly more subjective in approach than many current methodologies) is surely worth the Court considering afresh, ${ }^{152}$ as it seeks continually to ensure its authoritative voice in global affairs.

Ultimately, however, it is probably best if I leave the final word to Weeramantry himself; yet, in an effort to particularize the comment and to relate it more closely to his time on the bench, I have replaced the term "court" with "judge".

\footnotetext{
"The judicial function by its very nature involves a choice among competing principles all of which in one way or another have relevance to the matter in hand. What principles a [judge] adopts from the range of choice available is determined by a weighing of considerations such as those of relevance, immediacy to the problem, practical value in the particular circumstances, and the degree of authority of the principle. These are matters in which a [judge's] experience and sense of judgment
}

\footnotetext{
149 See text accompanying n. 36.

150 Although his view as to the binding nature of provisional measures has been accepted more widely by the Court (see n. 71) and his belief expressed in Case concerning East Timor (Portugal v. Australia) (1995) that a State could be held in explicit violation of self-determination was confirmed in Legal Consequences of the Construction of a Wall in the Occupied Palestinian Territory (2004). In neither case, of course, did the Court quote from Weeramantry.

151 Case Concerning Gabčikovo-Nagymaros Project (Hungary/Slovakia), ICJ Rep. 1997, 119.

152 ICJ Rep. 1997, at 96: "It would be a pity indeed if [such wisdom] were left untapped merely because of attitudes of formalism which see such approaches as not being entirely de rigueur."
} 
will provide [him] with guidance. In such situations, an important additional guide would be, within the limits of choice available in law, the [judge's] sense of justice, fairness and equity." 153

\section{ANNEX}

\section{(i) Separate and dissenting opinions}

Case concerning the Arbitral Award of 31 July 1989 (Guinea-Bissau v. Senegal), ICJ Rep. 1991, at 130-174, dissenting opinion

Case concerning Questions of Interpretation and Application of the 1971 Montreal Convention arising from the Aerial Incident at Lockerbie (Libyan Arab Jamahiriya v. United Kingdom) Request for the Indication of Provisional Measures, ICJ Rep. 1992, at 50-71, dissenting opinion Case concerning Questions of Interpretation and Application of the 1971 Montreal Convention arising from the Aerial Incident at Lockerbie (Libyan Arab Jamahiriya v. United States of America) Request for the Indication of Provisional Measures, ICJ Rep. 1992, at 160-181, dissenting opinion

Case concerning Maritime Delimitation in the Area between Greenland and Jan Mayen (Denmark v. Norway), ICJ Rep. 1993, at 211-279, separate opinion

Case concerning Application of the Convention on the Prevention and Punishment of the Crime of Genocide (Bosnia and Herzegovina v. Yugoslavia (Serbia and Montenegro)) Further Requests for the Indication of Provisional Measures, ICJ Rep. 1993, at 370-389, separate opinion

Case concerning East Timor (Portugal v. Australia), ICJ Rep. 1995, at 139-223, dissenting opinion

Request for an Examination of the Situation in Accordance with Paragraph 63 of the Court's Judgment of 20 December 1974 in the Nuclear Tests (New Zealand v. France) Case, ICJ Rep. 1995, at 317-362, dissenting opinion

Legality of the Use by a State of Nuclear Weapons in Armed Conflict, Advisory Opinion, ICJ Rep. 1996, at 101-171, dissenting opinion

Legality of the Threat or Use of Nuclear Weapons, Advisory Opinion, ICJ Rep. 1996, at 429555 , dissenting opinion

153 Case concerning Maritime Delimitation in the Area between Greenland and Jan Mayen (Denmark v. Norway), ICJ Rep. 1993, at 250. 
Case concerning Application of the Convention on the Prevention and Punishment of the Crime of Genocide (Bosnia and Herzegovina v. Yugoslavia) Preliminary Objections, ICJ Rep. 1996, at 640-655, separate opinion

Case Concerning Gabčíkovo-Nagymaros Project (Hungary/Slovakia), ICJ Rep. 1997, at 88-119, separate opinion

Case concerning Application of the Convention on the Prevention and Punishment of the Crime of Genocide (Bosnia and Herzegovina v. Yugoslavia) Counter-Claims, ICJ Rep. 1997, at 287297, dissenting opinion

Case concerning the Land and Maritime Boundary between Cameroon and Nigeria (Cameroon v. Nigeria) Preliminary Objections, ICJ Rep. 1998, at 362-376, dissenting opinion

Fisheries Jurisdiction Case (Spain v. Canada) Jurisdiction of the Court, ICJ Rep. 1998, at 496-515, dissenting opinion

Request for Interpretation of the Judgment of 11 June 1998 in the Case concerning the Land and Maritime Boundary between Cameroon and Nigeria (Cameroon v. Nigeria) Preliminary Objections (Nigeria v. Cameroon), ICJ Rep. 1999, at 42-48, dissenting opinion

Difference relating to Immunity from Legal Process of a Special Rapporteur of the Commission on Human Rights, Advisory Opinion, ICJ Rep. 1999, at 92-98, separate opinion

Case concerning Legality of Use of Force (Yugoslavia v. Belgium) Request for the Indication of Provisional Measures, ICJ Rep. 1999, at 181-204, dissenting opinion

Case concerning Legality of Use of Force (Yugoslavia v. Canada) Request for the Indication of Provisional Measures, ICJ Rep. 1999, at 315, dissenting opinion

Case concerning Legality of Use of Force (Yugoslavia v. Netherlands) Request for the Indication of Provisional Measures, ICJ Rep. 1999, at 599, dissenting opinion

Case concerning Legality of Use of Force (Yugoslavia v. Portugal) Request for the Indication of Provisional Measures, ICJ Rep. 1999, at 713, dissenting opinion

Case concerning Kasikili/Sedudu Island (Botswana/Namibia), ICJ Rep. 1999, at 1153-1195, dissenting opinion

Case concerning Sovereignty over Pulau Ligitan and Pulau Sipadan (Indonesia/Malaysia) Application by the Philippines for Permission to Intervene, ICJ Rep. 2001, at 630-651, separate opinion (as judge ad hoc) 


\section{(ii) Declarations}

Case concerning the Land and Maritime Boundary between Cameroon and Nigeria (Cameroon v. Nigeria) Request for the Indication of Provisional Measures, ICJ Rep. 1996, at 31, joint declaration of Judges Weeramantry, Shi and Vereshchetin

Case concerning Legality of Use of Force (Yugoslavia v. France) Request for the Indication of Provisional Measures, ICJ Rep. 1999, at 376, declaration

Case concerning Legality of Use of Force (Yugoslavia v. Germany) Request for the Indication of Provisional Measures, ICJ Rep. 1999, at 435, declaration

Case concerning Legality of Use of Force (Yugoslavia v. Italy) Request for the Indication of Provisional Measures, ICJ Rep. 1999, at 495, declaration

Case concerning Legality of Use of Force (Yugoslavia v. United Kingdom) Request for the Indication of Provisional Measures, ICJ Rep. 1999, at 842, declaration 